\section{alsunfyat}

JURNAL PENELITIAN BAHASA, SASTRA, DAN

BUDAYA ARAB

P-ISSN: 2615-7241 | E-ISSN: 2721-480X // Vol. 3 No. 1 | 1-14

(1) https://ejournal.upi.edu/index.php/alsuniyat/index

\title{
THE PRAGMALINGUISTICS OF APOLOGIZING IN THE ARABIC LANGUAGE BY NON-NATIVE SPEAKERS
}

\author{
Abdulkhaleq Al-Rawafi \\ Thamar University, Yemen \\ E-mail: rawafi2013@gmail.com
}

\begin{abstract}
:
Learners of a second language struggle to select and produce appropriate different kinds of speech acts due to their complexity. The students of the Islamic boarding schools are assigned to acquire two non-native languages compulsory and concurrently, namely Arabic and English. This study adapts the descriptive analytical approach to investigate the pragmalinguistic of the speech acts of apologizing in the Arabic language as produced by non-native speakers with special focus to the IFIDs. The participants are 202 students recruited to fill in a DCT that consists of eight situations regarding the students' violation of the rules of the school. The results show that the students tend to use certain semantic formulas of apologies due to their lack of linguistic proficiency. To conclude, these forms are template slots of the IFID in which the non-native apologizer can slot his/her apology within these templates, and hence, enrich their pragmatic competence ability.
\end{abstract}

Keywords:

Pragmalinguistics; Language transfer; Interlanguage pragmatics

\begin{abstract}
Abstrak:
Siswa pondok pesantren yang mempelajari bahasa kedua (bahasa asing) dituntut untuk memilih dan menghasilkan berbagai jenis tindak tutur yang tepat berdasarkan tingkat kompleksitasnya. Siswa juga diwajibkan untuk berbicara dengan mengunakan dua bahasa asing yaitu bahasa Arab dan bahasa Inggris. Dalam penelitian ini, peneliti menggunakan pendekatan deskriptif analitik untuk menyelidiki pragmalinguistik siswa dalam tindak tutur meminta maaf dengan menggunakan bahasa Arab dengan fokus khusus pada IFID. Partisipan dalam penelitian ini adalah 202 siswa (non-Arab) yang dipilih untuk mengisi DCT yang terdiri dari delapan situasi pelanggaran siswa terhadap aturan sekolah. Hasil penelitian menunjukkan bahwa para siswa cenderung menggunakan formula permintaan maaf tertentu karena kurangnya kemampuan dalam berbahasa Arab. Untuk menyimpulkannya, siswa memasukkan ungkapan permintaan maafnya kedalam templat IFID, dengan tujuan untuk memperkaya kemampuan pragmatik mereka.
\end{abstract}

Kata Kunci:

Pragmalinguistik; Transfer bahasa; Pragmatik antarbahasa

\section{INTRODUCTION}

The main concern of SLA is to explore the learners' acquisition of the L2 knowledge. Within this field, interlanguage pragmatic concerns its prime target in the implementation of pragmatic, i.e., the development of the linguistic actions by the non-native speakers (NNS). In other words, how does a NNS differ from a native speaker (NS) in the range of speech acts, the speech act strategies, their contextual distribution, linguistic forms to convey illocutionary meaning, and the degree of politeness (Kasper, 1992:204). All these ranges require the learners' ability to use appropriate language in an appropriate context, which is known as a 
'pragmatic competence'. In other words, pragmatic competence refers to the ability to use two types of knowledge, namely pragmalinguistic and sociopragmatic.

According to Leech $(1983,2014)$ pragmalinguistic is the NNS's ability to use linguistic forms and actins to convey a particular illocution, whereas sociolinguistic is the NNS' ability to fit these forms and action within a certain cultural context. In order to do that Celce-Murcia suggests that a successful communication requires various competence, namely 'linguistic competence', 'discourse competence', 'sociocultural competence', 'formulaic competence', interactional competence', and strategies competence' each of which contributes in a successful pragmatic performance in the target language, as cited in (Bagherkazemi, 2016:40). To this end, these types of competence might be combined into one competence, namely 'actional competence'; the skill that is needed in performing the speech acts in a non-native language.

Research on Interlanguage Pragmatic ILP focuses on the study of the non-native speakers competence in the performing of the speech acts of apologizing has been emerged since the 1980s. For example, studies concerning the comparison between the non-native speakers' realization of the speech acts of apologies in a non-native to their native languages (Blum-kulka \& Olshtain, 1983; Cohen \& Olshtain, 1980; Cohen \& Shively, 2007; Olshtain \& Cohen, 1981). Such studies are said to be the fundamental framework for further research regarding the non-native speakers' realization of the speech acts of apologies.

Building on their framework, many empirical studies emerged to explore the cultural variation in the realization of the apology strategies, comparing the non-native speakers to native speakers. Such studies are divided into two disciplines, namely cross-cultural pragmatic studies (e.g., focus on the sociolinguistic of apologizing) and interlanguage pragmatic studies (e.g., with focus to the linguistic forms of apologizing).

There are huge studies found in literature regarding the cross-cultural pragmatic studies concern with the non-native speakers realization of apology strategies, such as (AlZumor, 2011; Bataineh \& Bataineh, 2008; Nelson, Carson, Al Batal, \& El Bakary, 2002; Nureddeen, 2008). In the contrary, few studies are found regarding the interlanguage pragmatic with focus on the 'pragmatic transfer' and 'transferability', such as (Al-Zumor, 2011; Dendenne, 2016; Franch, Patricia, 1998; Kasper, 1992; Saleem \& Anjum, 2018; Takahashi, 1996). More recently, Leech (2014) discusses the pragmalinguistc of the speech acts of apologies in the British English with the focus on the Illocutionary Force Indicating Device 
(IFIDs). More specifically, the discussion concerns with the pragmalinguistic of the expressions of apologizing such 'I am sorry', 'I apologize', and 'forgive'.

To this end, the pragmalinguistic of the speech acts of apologies by non-native speakers of Arabic still one of the remaining issues and is the concentration of this study. More specifically, the study explores the extent to which the senior students of Islamic Bording schools in Indonesia use accurate pragmalinguistic in the realization of the apology strategies.

\section{METHOD}

\section{Instrument}

The instrument to collect the data for this study is a discourse completion task DCT. The DCT consists of eight situations about the school rules the students have to follow in boarding schools in Indonesia. The situations are designed carefully followed by a blank line in which the informants write their responses as they are in a real situation. These eight situations consists of the following themes late to school, late to class, smoke at school, having a mobile phone, bothering a younger student at school, using the belongings of the older student at school, through a trash in an improper place, and impolite communication.

\section{Participants}

The informants in this research are 202 students enrolled in a boarding school in Indonesia. They are chosen equally to fit gender differences; 101 male students and 101 female students. The same participants are assigned to fill in a questionnaire in Arabic.

\section{Procedure of Data Analysis}

The instrument formulated for eliciting the data for this study was not pilot-tested because such instrument is already tested in previous research. The analysis of the collected data is based on the apology strategies developed by (Blum-kulka \& Olshtain, 1983) and recently (Leech, 2014). The following strategies are the base of our analysis.

1) Illocutionary force indicating devices (IFIDs):
a. An expression of regret, e.g. I am sorry.
b. Offer an apology, e.g., I apologize.
c. Request for forgiveness, e.g., forgive me.

2) Explanation or account:

a. Explicit, e.g., the Traffic was terrible,

b. Implicit, e.g., traffic is always so heavy in the morning.

3) Taking on responsibility: 
a. Accepting the blame, e.g., It is my fault/my mistake,

b. Lack of intent, e.g., I didn't mean it,

c. Expressing self-deficiency, I was confused/I didn't see you/forgot,

d. Expression of embarrassment, e.g., I feel awful about it, Self-dispraise, e.g., I'm such a dimwit!, Justify hearer, e.g., You're right to be angry,

e. Refusal to acknowledge guilt, e.g., It was not my fault.

f. Blame the offended party, e.g., it is your own fault.

4) Promise for Forbearance, e.g., I promise I will not do it again.

5) Offer of repair, e.g. I'll pay for the damage, (6)

\section{RESULT AND DISCUSSION}

\section{The Pragmalinguistic of the IFIDs}

In order to explore the pragmalinguistics of the Aplogizing in the Arabic language as used by non-native speakers, it is essential to begin by classifying the students' responses based on the five semantic formulas of apologizing in the Arabic language, namely the Head Acts and the Supporting Moves. The following table summarizes the frequency of the occurrences of the students' apology responses.

TABEL 1THE FREQUENCY DISTRIBUTION OF THE STUDENTS' APOLOGY STRATEGIES

\begin{tabular}{|c|c|c|}
\hline Semantic formulas & $\mathbf{F}$ & $\%$ \\
\hline 1. IFIDs & 1651 & $50 \%$ \\
\hline $\begin{array}{l}\text { 2. Explanation } \\
\text { (account) }\end{array}$ & 297 & $9 \%$ \\
\hline $\begin{array}{l}\text { 3. Taking on } \\
\text { responsibility }\end{array}$ & 447 & $14 \%$ \\
\hline $\begin{array}{l}\text { 4. Promise for } \\
\text { forbearance }\end{array}$ & 709 & $21 \%$ \\
\hline 5. Offer of repair & 128 & $5 \%$ \\
\hline New found strategies & 25 & $1 \%$ \\
\hline $\begin{array}{l}\text { 6. Blame the offended } \\
\text { party. }\end{array}$ & & \\
\hline 7. Non-Verbal & 1 & $0 \%$ \\
\hline Total & 3285 & \\
\hline
\end{tabular}


Table 1 shows that the IFID strategy comes with (50\%) of the occurrence because it functions as the macroprposition of the apology in which the students are being explicit or direct. Hence, the other strategies are supportive moves with few occurrences. For example, the strategy Explanation comes with (9\%) where the students used internal (e.g., I am الطابور في and external factors (the queue in the canteen is long أنا إستغرقت في النومoverslept to claim their offences. However, the students tend to use the strategy Responsibility with (14\%) when the feel that the contacted the offence (e.g., it was my mistake followed by the use of Promise for Forbearance strategy with (21\%) to declare that they will not repeat that offence (e.g., I will not do it again لن أكرره مرة أخرى). Promise in some offences does not placate the offended party, however, Repair does (I will fix it أنا سأصلحه). The strategy Repair was more anticipated but unfortunately it comes with (5\%) only. The other supportive moves with few occurrences are Blame the offended party and NonVerbal with (1\%) only each.

To date, it is obvious that most of the students' apology strategies occur in the IFID strategy. Therefore, we limit the study to the pragmalinguistic of the Head Act apology semantic formulas. In the Head Act, we found three sub-strategies in the male and female students' responses in the Arabic language. These are; the expression of regret strategy (e.g., asif عفى آسف 'I apologize'), and request for forgiveness (e.g., samihni سامحني'forgive me').

Building on the analysis of the data, the study came up with various forms of apologizing in the Arabic language. Based on these forms, we would like to introduce a fixed system of apologizing. The system consists of a 'template skeleton' (the concept is adapted from Templatic Morphology of Semitic languages). We believe that these forms, if added to the curriculum of the Arabic language for non-native speakers, may develop the students' pragmatic competence and build their extraordinary proficiency of apologizing in the Arabic language. The list 1 through 16 illustrates the most used forms of apologizing by non-native speakers.

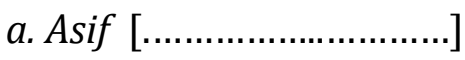
b. $[$......................................] asif
C. Asif $\quad[$..............................] asif
d. A'tathir $[. . . . . . . . . . . . . . . . . . . . . . .$.$] asif$

Vol. 3 No. 1 | 1-14

ALSUNIYAT, p-ISSN: 2615-7241, e-ISSN: 2721-480X 

e. A'tathir [. ] samih
f. Afwan [.............................. afwan
g. Afwan [........................ muta'sifah
h. Afwan jiddan [......................] afwan jiddan
i. Ana haqqan asif [................] ana asif jiddan
j. Asif [..............][asif jiddan] [..............] asif
k. Asif [............................... ] samih
l. Asif […..........................] asif haqqan.
m. Asif [ [..............................] khilafjiddan
n. Asif [......]asif jiddan [..........] igfir/samih.
o. Asifjiddan [................]asif [............] asif.

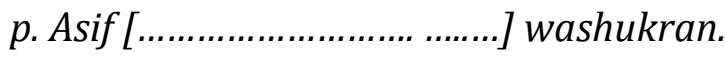
q. Asi $f[\ldots \ldots \ldots \ldots \ldots \ldots \ldots \ldots \ldots \ldots \ldots \ldots . . . . .1$ iqfir.
r. Muta'sif [........................... tawbah
s. Samih [............................] asif.

Whereas the IFID is an essential element in the forms of apologizing, the offender chooses a particular form and slots the suitable supportive move, or other linguistic actions such as intensifiers, to strengthen the apology and placate the offended party. There are four possible templates construe this system:
a) IFID + [slot area].
b) [slot area] + IFID.
c) IFID + [slot area] + IFID.
d) IFID + [slot area] + IFID + [slot area] + IFID.

What is interesting in these templates is that the non-native speakers prefer to use the third template as it is the most common frequent, in which the IFID holds initial and postposition and the slot area may include more than one supportive move. It is crucial to emphases the use of one template over the other. Therefore, to clarify that it is crucial to explore the pragmalinguistics of the three basic elements of apologizing in the Arabic language. In other words, the three sub-strategies of the IFID apology expressions used in the Head Acts, mainly their placement, linking patterns, and levels of elaboration. 
1) Asif/ana asif آسف، أنا آسف'Sorry'/'I am sorry'

The Arabic apologetic word asif آسف whether precedes with a pronoun or comes as an isolated form, is the most common expression that expresses regret. Interestingly, unlike the English equivalent apologetic word 'sorry' or the expression 'I am sorry' that has two frequent functions, namely, as a declarative and as an interrogative, the Arabic apologetic word asif آسف 'sorry' has only one usage, namely a declarative.

The other pragmalinguistic syntactical formula of the apologetic word asif آسف is its placement in a declarative sentence. There are three different locations of the expression asif in a sentence, namely initial position, middle position, and ending position. It is worth noting that when the word asif آسف 'sorry' holds an intial and post-position, the apologetic word asif سف in the initial position functions as solidarity and spiritual sympathy towards the offended party, whereas that expresses the real regret in the post-position.

There are linking patterns used to link the IFID to other strategies. For example, the expression asifis linked to other supportive moves by the following propositions:

\section{TABEL 2 LINKING PATTERNS OF THE EXPRESSION REGRET STRATEGY}

\begin{tabular}{ccl}
\hline \multicolumn{1}{c}{ Form } & Meaning & \multicolumn{1}{c}{ Function } \\
\hline Asif lan ... & 'sorry+not... & Promise \\
Asif li...... & 'sorry+for/about' & Account \\
Asif sa..... & 'sorry+will' & Repair \\
Asif wa .... & 'sorry+but' & Responsibility \\
\hline
\end{tabular}

These are the most common linking patterns of the IFID asif to the other supporting move.

The data analysis shows that the students tend to extend their apologies up to five levels. This is known as the elaboration of the semantic formulas. Hence, the researcher prefers to use the Level of Elaboration' (LoE). Previous research used the concept 'combination' or sequence of strategies' (Al-Luhaibi \& Ya'Allah, 2014; Blum-kulka \& Olshtain, 1983, p. 208). In this study, the LoE refers to the sequence or the length of the students' apology semantic formula by which the students strengthen their 'regret sincerity for the injured person's feeling'(Ahmed, 2017, p. 138). The following points represent the LoE of the IFID semantic formula Expression of regret strategy. 
$1 \quad$ IFID $r$

2 IFID $r \quad$ FORBE

3 IFID r EXPL. FORBE

4 IFID $r \quad$ EXPL. $\quad$ FOPRBE $\quad$ IFID

$\begin{array}{lllll}5 & \text { IFID } \mathrm{r} & \text { RESP. } & \text { IFID } & \text { FORBE }\end{array}$

Thus, the shortest level consists of one level and the longest level consists up to five levels. It has been suggested that short apology is a native norm, whereas the long sequence shows the less appropriate apology. It reflects the students' low proficiency in a non-native language in the sense that their apology contains too many words.

2) Afwan عفواً, a'tathir عتنر/apologize'

Like the offer an apology strategy in the English language that consists of two performative verbs 'apologize' and 'pardon', the offer an apology strategy is expressed by using the expression afwan 'apologize' and the performative verb a'tathir 'apologize' in the Arabic language. Terminologically, the expression afwan is a noun from the stem afa (apologized) and the performative verb a'tathir is from the performative verb athar.

Offer an apology is the second common apology strategy used by the students. The findings showed that the students prefer to use the expression afwan rather than the performative verb ' $a$ 'tathir'. This happens due to the fact that the pragmatic function of the two expressions differs. In other words, the expression afwan is pragmatically used to remedy light offences whereas, in some cases, the perfromative a'tathir used to remedy severe offences. It is worth noting that when the students write their responses in Latin alphabets they tend to use the expression afwan, whereas if they write their responses in the Arabic alphabet they use the performative verb a'tathir with some exceptions. This phenomenon is known as pragmalinguistic transfer.

As function, the expression afwan and the performative verb a'tathir, have two pragmatic usages, namely as a declarative form followed by a full stop and as an interrogative form followed by a question mark. The students prefer to use the declarative form and leave aside the interrogative form.

Like the expression of the regret strategy, the expression afwan and the performative verb a'tathir of the offer an apology strategy holds initial position and post- 
position. In the initial position, the expression afwan is not preceded with a pronoun whereas the performative verb 'a'tathir' can be preceded and followed with pronouns or personal names.

Linking patterns are propositions used to link two apology strategies (Leech, 2014). It is obvious that the students use different linking patterns to connect the IFID strategy with the strategies to strengthen their offer of apology. These linking patterns are an 'for', li 'because', bi 'with', wa sawfa 'and will', ya 'oh', and amma 'for'. Each of which has a pragmatic function. For example, the pronoun an 'for', li 'because', amma 'for' are used to justify that the offence is occurred due to external or internal factors out of his/her control. By the use of the use of the bi 'with', the students offer the offended party a repair in order to placate them and to fulfill the function of the apology. The following table presents the linking patterns of this sub-strategy.

TABEL 3 LINKING PATTERNS OF THE OFFER AN APOLOGY STRATEGY

\begin{tabular}{lll}
\hline Form & Meaning & Function \\
\hline A'tathir an ... & apologize + for & Account \\
\hline A'tathir li ... & Apologize + because & Account \\
\hline A'tathir bi ... & Strongly Apologize & Intensify \\
\hline A'tathir wa sawfa... & Apologize +will & Repair \\
\hline A'tathir amma.. & Apologize+for & Account \\
\hline
\end{tabular}

As Table 3 demonstrates, the linking patterns of the offer an apology were used to link the performative verb a'tathir and the expression afwan with the supportive moves. The expression afwan is directly linked with the titles and the personal names of the offended parties.

Regarding the elaboration of the offer an apology strategy, the students found that the students elaborate their apology with a sequence up to three levels. These levels are illustrated below.

1 IFID o

2 IFID o EXPL/FORBE/REP 
3) Samihni سامحنيand igfirli أغفر لي 'forgive me'

The third strategy is the request for forgiveness. In the Arabic culture, request for forgiveness strategy is the most effective strategy to remedy any type of offence (Al-luhaibi \& Ya'llah, 2014). The semantic formula of this strategy consists of two performative verbs igfir and samih mean 'forgive'. Terminologically, these two verbs have the roots forms gafara and samha (forgive) respectively.

The students of boarding schools used this strategy less frequently; male $(n=11)$ and female $(n=9)$ occurrences. As function, the two expressions of request for forgiveness strategy were used as an imperative and interrogative mood in a sentence to function as request for forgiveness. Interestingly, in order to soften the imperative mood and show the students' politeness towards the offended parties, the students intensified the performative verbs samih and igfir by inserting the Arabic mitigate request speech act device 'arju' means 'please', as in arjuk samihni 'please, forgive me' or arjuk igfirlii 'please, forgive me'.

Like the offer an apology strategy, the request for forgiveness strategy is placed in an initial position and post-position. Its main pragmatic function is to request apology not to show sympathy.

Linking patterns are used to link the IFID as for forgiveness that is located in the initial positions with the Supportive Moves.

TABEL 4 LINKING PATTERNS OF THE REQUEST FOR FORGIVENESS STRATEGY

\begin{tabular}{lll}
\hline Form & Meaning & Function \\
\hline Samihni sa ... & Forgive me + will & Repair \\
Samihni lianna ... & Forgive me + because & Account \\
Samihni lan... & Forgive me + not & Promise \\
Igfir li liana ... & Forgive me + because & Account \\
Samih ya ... & Forgive me + (o) & Addressing \\
Samihni la ... & Forgive me + do not & Request 'prohibition' \\
\hline
\end{tabular}




\section{Samih if ... $\quad$ Forgive me + if $\quad$ Denying 'conditional'}

As Table 4 demonstrates, these patterns are the most common linking patterns found in the Arabic data. The performative verbs samih and igfir located in the initial positions are followed by either comma or full stop, as in ('samihni, ...' or 'samihni.'). Regarding the elaboration of the request for forgiveness strategy to other supportive moves, it shows that the students tend to elaborate their apology up to four levels. These four linguistic levels are listed below.

1 IFID $\mathrm{f}$

2 IFID $\mathrm{F} \quad$ FORBE

3 IFID $f \quad$ REP. FORBE

4 REP. $\quad$ FORBE. Swear $\quad$ IFID $\mathrm{f}$

The four levels represent the elaboration system or the length of the semantic formulas found in the students' apology strategies responses in the Arabic language.

This study explored the pragmalinguistic of the Illocutionary Force Indicating Device IFID strategy as used by the students of the Islamic Boarding schools in Indonesia when apologizing in the Arabic language as a non-native language about the violation of the eight situations concerning the rules of the Islamic Boarding schools. The speech acts of apologies has been researched in the Arabic language by native speakers (Al-Luhaibi \& Ya'Allah, 2014; Al-Zumor, 2011; Nelson et al., 2002; Nureddeen, 2008); however, the pragmalinguistic of the apology strategies (e.g., the IFID strategy) has not been explored as produced by native or non-native speakers of the Arabic language. The question of this was sat to analyze the students' use of the linguistic forms within the IFID strategy and how do they degree of its elaboration. It has been found that the pragmalinguistic of the apology strategies as used by the non-native speakers in the Arabic language is nativelike to some extent due to a 'consequence of positive L1 pragmatic transfer' (Cohen \& Shively, 2007, p. 191). Although the students' realization of the apology strategies in the Arabic language as native-like, there are still linguistic actions or linguistic forms that are influenced by the pragmatic transfer from the students' L1 language. For example, the students inclined to use less affective expressions of the IFID to regret for offences with 
high-degree of imposition such as asif 'sorry', whereas asif is used by the Arabs to remedy mild offences only (Abu Humei, 2013; Ahmed, 2017; Al-luhaibi \& Ya'llah, 2014). In addition, the students tend to elaborate their IFID strategies up to five levels to strengthen their apologies, placate the offended party, and to beg the forgiveness from the offended parties.

Many studies has confirmed that 'pragmatic transfer is the influence exerted by the learner's pragmatic knowledge of languages other than the L2 on the comprehension and production of the L2 pragmatic information' (Kasper, 1992, p. 207). Therefore, the students tend to use positive pragmalinguistic in the Arabic language. It has been indicating from the linguistic forms of the IFID that construe a template skeleton of apologizing by which the non-native apologizer might choose the suitable template and insert within that the supportive move or the internal and external modifiers to suit the offence.

\section{CONCLUSION}

The study concluded that the students of boarding schools tend to use positive pragmalinguistic to some extent, however, there are still linguistic forms exerted from their L1 and transferred to the L2. In this regard, their selection of certain linguistic form over others might be attributed to their lack of proficiency in performing the speech acts of apologies in the Arabic language. Interestingly, this study was able to manipulate linguistic forms that consist of templatic skeleton by which can be adapted by the intermediate non-native speakers of the Arabic language.

\section{REFERENCES}

Abu Humei, A. M. A. A.-A. (2013). The Effect of Gender and Status on the Apology Strategies Used by American Native Speakers of English and Iraqi EFL University Students. Research on Humanities and Social Sciences, 3(2), 145-173. https://doi.org/10.7575/aiac.ijalel.v.3n.5p.91

Ahmed, A. H. (2017). The Pragmatics of Apology Speech Act Behaviour in Iraqi Arabic and English. De Montfort University_UK.

Al-Luhaibi, F. M., \& Ya'Allah, M. S. (2014). Shifting Responsibility Strategies : Apology in Saudi Arabia. Journal of Language and Literature, 14(1), 3-29.

Al-luhaibi, F. M., \& Ya'llah, M. S. (2014). Shifting Responsibility Strategies : Apology in Saudi 
Arabia. Journal of Faculty of Arts and Linguistics, 14 \& 15, 3-29.

Al-Zumor, A. W. Q. G. (2011). Apologies in Arabic and English: An inter-language and crosscultural study. Journal of King Saud University - Languages and Translation, 23(1), 19-28. https://doi.org/10.1016/j.jksult.2010.02.001

Bagherkazemi, M. (2016). Interlanguage Pragmatics : A Compendium of Theory and Practice. Journal of Applied Linguistics and Language Research, 3(5), 38-53.

Bataineh, R. F., \& Bataineh, R. F. (2008). A cross-cultural comparison of apologies by native speakers of American English and Jordanian Arabic. Journal of Pragmatics, 40(4), $792-$ 821. https://doi.org/10.1016/j.pragma.2008.01.003

Blum-kulka, S., \& Olshtain. (1983). Requests and Apologies : A Cross-Cultural Study of Speech Act Realization Patterns ( CCSARP ). Applied Linguistics, 5(3), 196-213. https://doi.org/10.1093/applin/5.3.196

Cohen, A. D., \& Olshtain, E. (1980). DEVELOPING A MEASURE OF SOCIOCULTURAL COMPETENCE : THE CASE OF APOLOGY' The Hebrew University of Jerusalem. Language Learning, 31(1), 113-134.

Cohen, A. D., \& Shively, R. L. (2007). Acquisition of requests and apologies in Spanish and French: Impact of study abroad and strategy-building intervention. Modern Language Journal, 91(2), 189-212. https://doi.org/10.1111/j.1540-4781.2007.00540.x

Dendenne, B. (2016). Pragmatic Transfer in Requests and Apologies Performed by Algerian EFL Learners : A Cross-cultural and Interlanguage Pragmatic Study.

Franch, Patricia, B. (1998). On Pragmatic transfer. Studies in English Language and Linguistics, 5-20. https://doi.org/10.1177/026765839200800303

Kasper, G. (1992). Pragmatic transfer. Second Language Research, 8(3), 203-231. https://doi.org/10.1177/026765839200800303

Leech, G. (1983). Principles of Pragmatics. London and New York: Longman.

Leech, G. (2014). The Pragmatics of Politeness. New York: Oxford University Press.

Nelson, G. L., Carson, J., Al Batal, M., \& El Bakary, W. (2002). Cross-Cultural Pragmatics: Strategy Use in Egyptian Arabic and American English Refusals. Applied Linguistics, 23(2), 163-189+280. https://doi.org/10.1093/applin/23.2.163

Nureddeen, F. A. (2008). Cross cultural pragmatics: Apology strategies in Sudanese Arabic. Journal of Pragmatics, 40(2), 279-306. https://doi.org/10.1016/j.pragma.2007.11.001

Olshtain, E., \& Cohen, A. D. (1981). Apology : a speech-act set. Language Learning, 31(1), 113- 
ALSUNIYAT: Jurnal Penelitian Bahasa, Sastra, dan Budaya Arab

134.

Saleem, T., \& Anjum, U. (2018). Pragmatic Transfer in Pakistani English Speakers Apology Responses : Impact of Social Power. FWU Journal of Social Sciences, 12(2), 74-98.

Takahashi, S. (1996). Pragmatic Transferability. SSLA, 18(October 1994), 189-223. 